\title{
From "traction bronchiectasis" to honeycombing in idiopathic pulmonary fibrosis: A spectrum of bronchiolar remodeling also in radiology?
}

\author{
Sara Piciucchi ${ }^{1 *}$, Sara Tomassetti ${ }^{2}$, Claudia Ravaglia ${ }^{2}$, Christian Gurioli², Carlo Gurioli ${ }^{2}$, Alessandra Dubini ${ }^{3}$, \\ Angelo Carloni ${ }^{4}$, Marco Chilosi ${ }^{5}$, Thomas V Colby ${ }^{6}$ and Venerino Poletti ${ }^{2,7}$
}

\begin{abstract}
Background: The diagnostic and prognostic impact of traction bronchiectasis on high resolution CT scan (HRCT) in patients suspected to have idiopathic pulmonary fibrosis (IPF) is increasing significantly.

Main body: Recent data demonstrated that cysts in honeycombing areas are covered by epithelium expressing bronchiolar markers. In IPF bronchiolization is the final consequence of a variety of pathogenic events starting from alveolar stem cell exhaustion, and ending in a abnormal/dysplastic proliferation of bronchiolar epithelium. CT scan features of traction bronchiectasis and honeycombing should be interpreted under the light of these new pathogenetic and morphologic considerations.
\end{abstract}

Short conclusion: We suggest that in IPF subjects traction bronchiectasis and honeycombing -now defined as distinct entities on HRCT scan- are actually diverse aspects of a continuous spectrum of lung remodeling.

Keywords: Traction bronchiectasis, Honeycombing, Fibroblastic Foci, Bronchiolar dysplastic proliferation

\section{Background}

Histologically, Usual Interstitial Pneumonia (UIP) is characterized by a combination of "patchy fibrosis" and fibroblastic foci displaying a "patchwork pattern". Disease progression is characterized by the appearance of airspaces lined by plump cuboidal or even ciliated columnar cells showing a immunohistochemical and molecular bronchiolar phenotype [1-3].

In the recent years, the role of bronchiolar epithelium in the development of UIP pattern (in IPF subjects) has been widely emphasized [4-8].

Factors leading to lung remodeling include senescence, alveolar stem cell exhaustion and consequently aberrant activation of the wnt- $\beta$-catenin and hedgehog pathways that normally regulate branching morphogenesis in the lungs $[6,9]$.

\footnotetext{
* Correspondence: piciucchi.sara@gmail.com

'Department of Radiology, Azienda USL Romagna, Ospedale GB Morgagni,

Via C. Forlanini, Forlì FC 34-47121, Italy

Full list of author information is available at the end of the article
}

Mechanical stress may contribute to the subpleural and usually basilar localization of UIP changes [10, 11].

The final stage of this "bronchiolization" process corresponds radiologically to honeycombing, typically seen first in the subpleural regions of the lower lobes $[2,3]$.

\section{Main text}

By CT, a "definite" usual interstitial pneumonia (UIP) pattern, as seen in IPF, is characterized by the presence of reticulation, traction bronchiectasis and honeycombing in a basal and peripheral predominant distribution. The presence of honeycombing and traction bronchiectasis, besides reticulation, is crucial [12-19].

However if we reconsider morphological aspects in light of the pathogenic events discussed above, we identify some interesting key points in the interpretation of CT findings.

First, the sites in which mechanical stress and remodeling are highest, correspond to the areas in which traction bronchiectasis and honeycombing appear. 


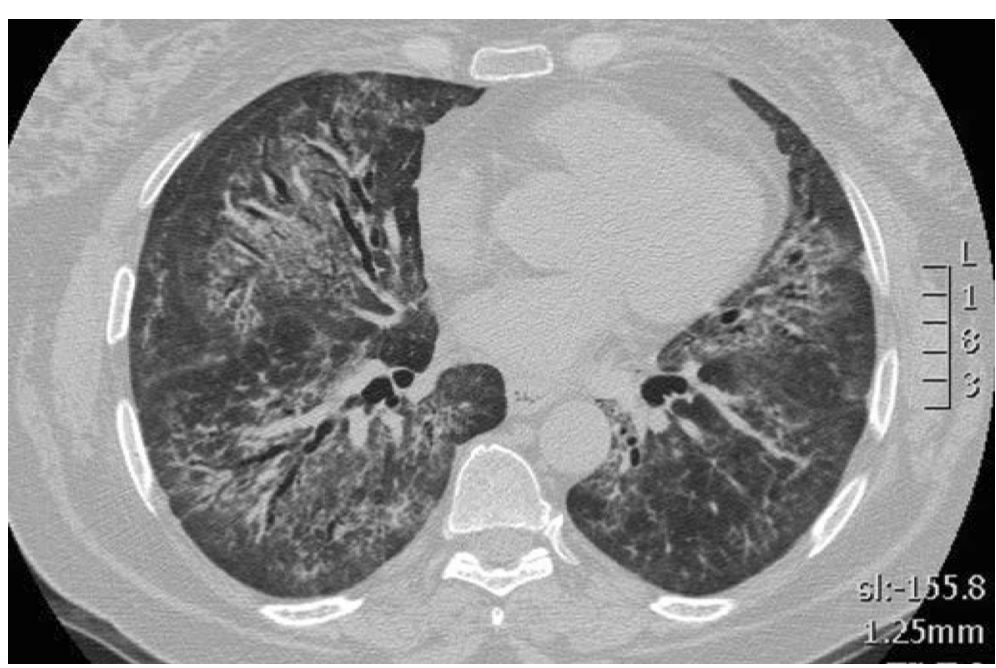

Fig. 1 CT scan of a 52 years old lady, affected by idiopathic NSIP. Bilateral, peribronchovascular ground glass attenuation, due to intralobular fibrotic changes. Traction bronchiectasis are present bilaterally surrounded by ground glass,"fibrotic" attenuation, mainly in the right middle lobe and in both lower lobes. No honeycombing is present. A relative subpleural sparing is also visible

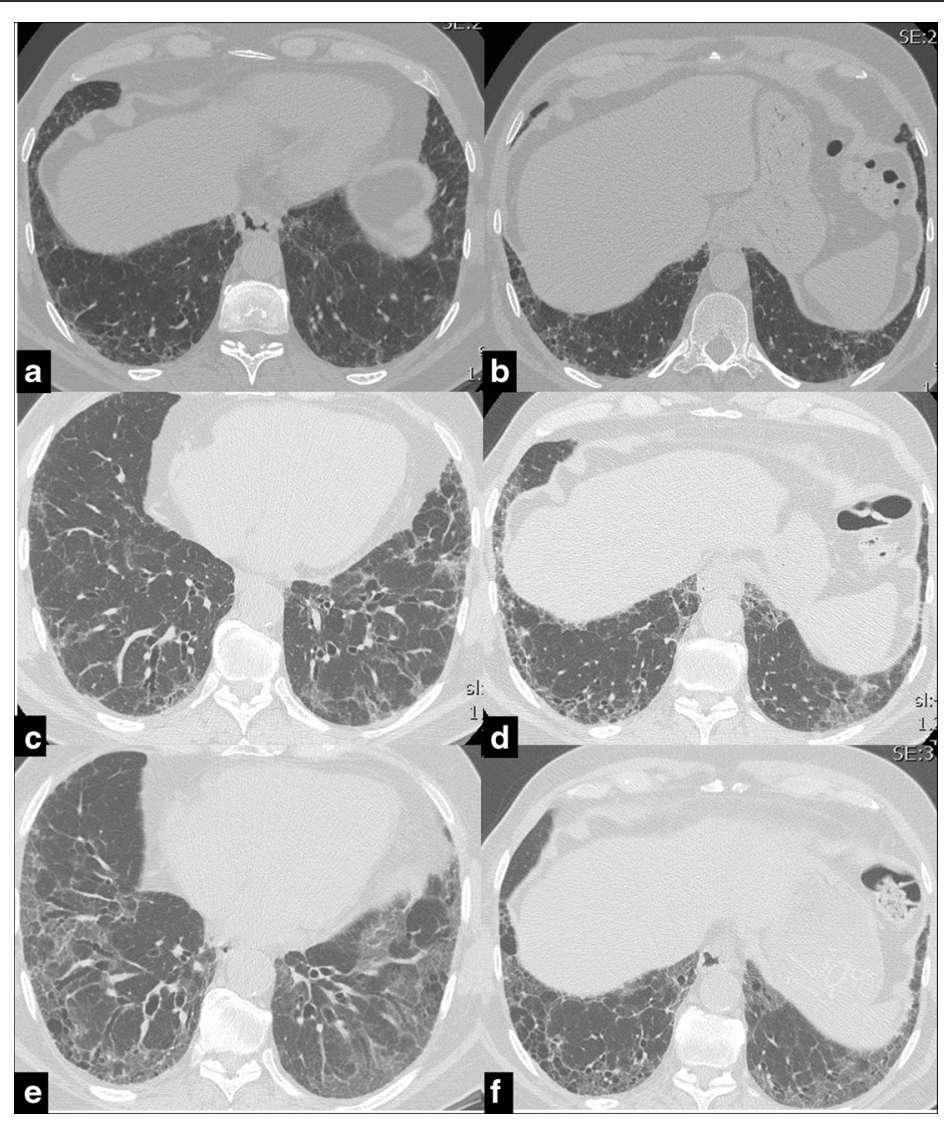

Fig. 2 Serial CT images of a 63 years old male affected by IPF. UIP pattern has been diagnosed through surgical lung biopsy at diagnosis. CT shows the progressive worsening of the coarseness. In 2007 (a, b) a moderate peripheral fibrotic reticulation is present. In the following years it progressively gets worse, particularly in the right lower lobe, with increase of the extension of traction bronchiectasis in 2010 (c, $\mathbf{d}$ ) and with honeycombing and traction bronchiectasis in 2014 (e, f) 
Second, most of the "scarred" tissue is in the region distal to the traction bronchiectasis, beneath the pleura, and does not concentrically surround the dilated bronchi. Conversely in nonspecific Interstitial Pneumonia (NSIP), traction bronchiectasis is completely surrounded by the fibrotic tissue (Fig. 1).

Furthermore as the fibrosis progresses, dilatation of the airways increases in severity from the periphery to the inner third of the lungs, passing from a score 1 (more peripheral) to 3 (from periphery to the inner third of the parenchyma) [score proposed by Edey et al. [20]] (Fig.2).

In CT scans, when fibrosis is more severe, bronchiectasis tend to follow the convexity of the pleura and to overlap with honeycombing features [21].

Therefore, also in CT scans, traction bronchiectasis observed in IPF subjects is better interpreted as resulting from bronchiolar proliferation rather than from pure mechanical traction of a single airway by scarring tissue. Supporting this point of view is the recent observation by Staats et al. [4] on explanted lungs obtained from patients with IPF. They showed a positive correlation between honeycombing assessed by $\mathrm{CT}$ and bronchiolectasis $(\mathrm{p}=0.001)$ and respiratory-lined cysts $(\mathrm{p}=0.001)$ histologically counted. If we consider traction bronchiectasis as the solely consequence of pure mechanical traction around the airway, this process should result in a relatively stable number of traction "holes" with an enlargement of lumen reaching the periphery, as actually is present only in NSIP. Thus, in IPF, remodeling process appears to be a continuum from traction bronchiectasis to honeycombing and conceptual separation of the two processes may be misleading.

Walsh et Al. [19] reinforced this concept recently. The authors retrospectively reviewed radiological features of 162 biopsy proven cases of UIP and NSIP, delineating a radiological visual score for each case and correlating these radiological data to the fibroblastic foci profusion score and other morphologic aspects. They concluded that in UIP there was a strong correlation between traction bronchiectasis, honeycomb changes and fibroblastic foci profusion. In conclusion, according to the "alveolar stem cell exhaustion" model explaining at least part of the pathogenic events in IPF [14] we suggest that traction bronchiectasis and honeycombing is a unique and continuous process of bronchiolar dysplastic proliferation and to interpret accordingly the HRCT features.

\section{Conclusions}

In agreement to the "alveolar stem cell exhaustion pathogenic model" in IPF, we may begin to consider traction bronchiectasis and honeycombing as a unique and continuous process of bronchiolar proliferation also in HRCT scan.

\section{Abbreviations}

UIP: Usual Interstitial Pneumonia; NSIP: non specific interstitial pneumonia; IPF: idiopathic pulmonary fibrosis; HRCT: high resolution computed tomography.

\section{Acknowledgements}

We are very grateful to Dr Paola Tantalocco, biomedical engineer and data manager of our Institution for her important contribution to our research activity.

\section{Funding}

No funders.

Availability of data and materials

Availability of data and materials.

\section{Authors' contributions}

$S P, S T, C R, C h G, C G, A D, A C, M C, T V C, V P$ : participated in the design of the study. SP, TVC, VP: participated in its design and coordination and helped to draft the manuscript. All authors read and approved the final manuscript.

\section{Competing interests}

The authors declare that they have no competing interests.

\section{Consent for publication}

Not applicable.

Ethics approval and consent to participate

Not applicable.

\section{Author details}

'Department of Radiology, Azienda USL Romagna, Ospedale GB Morgagni, Via C. Forlanini, Forli FC 34-47121, Italy. ${ }^{2}$ Department of Diseases of the Thorax, Azienda USL Romagna, Ospedale GB Morgagni, Forli, Italy. ${ }^{3}$ Department of Pathology, Azienda USL Romagna, Ospedale GB Morgagni, Forlì, Italy. ${ }^{4}$ Department of Radiology, Ospedale Santa Maria, Terni, Italy. ${ }^{5}$ Department of Pathology and Diagnostics, University of Verona, Verona, Italy. 'Department of Laboratory Medicine and Pathology, Mayo Clinic, Scottsdale, AZ, USA. ${ }^{7}$ Department of Respiratory Diseases \& Allergy, Aarhus University Hospital, Aarhus, Denmark.

Received: 17 December 2015 Accepted: 11 May 2016 Published online: 23 May 2016

\section{References}

1. Chilosi M, Poletti V, Murer B, Lestani M, Cancellieri A, Montagna L, Piccoli P, Cangi G, Semenzato G, Doglioni C. Abnormal re-epithelialization and lung remodeling in idiopathic pulmonary fibrosis: the role of deltaN-p63. Lab Invest. 2002;82:1335-45.

2. Katzenstein AL. In: Saunders WB, editor. Katzenstein and Askin's Surgical Pathology of Non-Neoplastic Lung Disease: Volume 13; the Major Problems in Pathology Series. 2006.

3. Seibold MA, Smith RW, Urbanek C, Groshong SD, Cosgrove GP, Brown KK, Schwarz MI, Schwarz DA, Reynolds SD. The idiopathic pulmonary fibrosis honeycomb cyst contains a mucocilary pseudostratified epithelium. PLoS One. 2013:8:1-9.

4. Staats P, Kligerman S, Todd N, Tavora F, Xu L, Burke A. A comparative study of honeycombing on high resolution computed tomography with histologic lung remodeling in explants with usual interstitial pneumonia. Pathol Res Pract. 2015;211:55-61.

5. Ryu JH, Moua T, Daniels CE, Hartman TE, Yi ES, Utz JP, Limper AH. Idiopathic pulmonary fibrosis: evolving concepts. Mayo Clin Proc. 2014;89:1130-42.

6. Chilosi M, Carloni A, Rossi A, Poletti V. Premature lung aging and cellular senescence in the pathogenesis of idiopathic pulmonary fibrosis and COPD/emphysema. Transl Res. 2013;162:156-73.

7. Gransner JM, Rosas IO. Telomeres in lung disease. Transl Res. 2013;162:343-52.

8. Selman M, Pardo A, Kaminski N. Idiopathic pulmonary fibrosis: aberrant recapitulation of developmental programs? Plos Medicine. 2008;5:373-80.

9. Chilosi M, Zamò A, Doglioni C, Reghellin D, Lestani M, Montagna L, Pedron S, Ennas MG, Cancellieri A, Murer B, Poletti V. Migratory marker expression in fibroblast foci of idiopathic pulmonary fibrosis. Respir Res. 2006;7:95. 
10. Carloni A, Poletti V, Fermo L, Bellomo N, Chilosi M. Heterogeneous distribution of mechanical stress in human lung: A mathematical approach to evaluate abnormal remodeling in IPF. Journal of Theoretical Biology. 2013:32-336.

11. Leslie KO. Idiopathic pulmonary fibrosis may be a disease of recurrent, tractional injury to the periphery of the aging lung: a unifying hypothesis regarding etiology and pathogenesis. Arch Pathol Lab Med. 2012;136: 591-600.

12. Raghu G, Collard HR, Egan JJ, et al. An official ATS/ERS/JRS/ALAT statement: idiopathic pulmonary fibrosis: evidence-based guidelines for diagnosis and management. Am J Respir Crit Care Med. 2011;183:788-824.

13. Sverzellati N. Highlights of HRCT imaging in IPF. Respir Research. 2013;14:S3.

14. Lynch DA, Godwin JD, Safrin S, Starko KM, Hormel P, Brown KK, et al. Highresolution computed tomography in idiopathic pulmonary fibrosis: diagnosis and prognosis. Am J Respir Crit Care Med. 2005;172:488-93.

15. Ley B, Ryerson CJ, Vittinghoff E, Ryu JH, Tomassetti S, Lee JS, et al. A multidimensional index and staging system for idiopathic pulmonary fibrosis. Ann Intern Med. 2012;156:684-91.

16. Walsh SL, Sverzellati N, Devaraj A, Keir GJ, Wells AU, Hansell DM. Connective tissue disease related fibrotic lung disease: high resolution computed tomographic and pulmonary function indices as prognostic determinants. Thorax. 2014;69: 216-222.

17. King Jr TE, Schwarz MI, Brown K, Tooze JA, Colby TV, Waldron Jr JA, et al. Idiopathic pulmonary fibrosis: relationship between histopathologic features and mortality. Am J Respir Crit Care Med. 2001;164:1025-32.

18. Nicholson AG, Fulford LG, Colby TV, du Bois RM, Hansell DM, Wells AU. The relationship between individual histologic features and disease progression in idiopathic pulmonary fibrosis. Am J Respir Crit Care Med. 2002;166:173-7.

19. Walsh SL, Wells AU, Sverzellati N, Deveraj A, Von der Thusen J, Yousem SA, Colby TV, Nicholson AG, Hansell DM. Relationship between fibroblastic foci profusion and high resolution CT morphology in fibrotic lung disease. Medicine. 2015;13:241-9.

20. Edey A, Devaray AA, Barker RP, Nicholson AG, Wells AU, Hansell DM. Fibrotic idiopathic interstitial pneumonias: HRCT findings that predict mortality. Eur Radiol. 2011;21:1586-93.

21. Watadani T, Sakai F, Johkoh T, Noma S, Akira M, Fujimoto K, Bankier AA, Lee KS, Müller NL, Song JW, Park JS, Lynch DA, Hansell DM, Remy-Jardin M, Franquet $T$, Sugiyama $Y$. Interobserver variability in the $C T$ assessment of honeycombing in the lungs. Radiology. 2013;266:936-44.

\section{Submit your next manuscript to BioMed Central and we will help you at every step:}

- We accept pre-submission inquiries

- Our selector tool helps you to find the most relevant journal

- We provide round the clock customer support

- Convenient online submission

- Thorough peer review

- Inclusion in PubMed and all major indexing services

- Maximum visibility for your research

Submit your manuscript at www.biomedcentral.com/submit 